\title{
Effectiveness of additives in spray drying performance: a review
}

\author{
${ }^{1}$ Lee, J.K.M, ${ }^{1 *}$ Taip, F.S. and ${ }^{2}$ Abdullah. Z., \\ ${ }^{1}$ Department of Process and Food Engineering, Faculty of Engineering, Universiti Putra Malaysia, 43400, \\ UPM Serdang, Selangor, Malaysia. \\ ${ }^{2}$ Faculty of Chemical Engineering, Universiti Teknologi Mara, 40450 Shah Alam, Selangor Malaysia
}

\author{
Article history: \\ Received: 3 July 2018 \\ Received in revised form: 3 \\ September 2018 \\ Accepted: 27 September 2018 \\ Available Online: 6 \\ November 2018 \\ Keywords: \\ Spray drying, \\ Additives, \\ Powder quality, \\ Process parameter
}

DOI:

https://doi.org/10.26656/fr.2017.2(6).134

\begin{abstract}
The systemic review covers the efficiency of additives on spray dried product; process parameter and its physicochemical properties. Due to the demand of diversification of food products, conventional spray drying process has gained momentum in drying process and extensively used to preserve food materials in powder form. Regarded as a complex operation, the balance between optimization of spray drying process parameters and physiochemical of its product has proven to be a challenge, especially in low product yield due to low transition temperature of feed material. This paper envelope the usage of additives as carriers in spray drying processes, and its effects on physicochemical properties such as hygroscopicity, flavour retention, and colour indexing. The literature signified the vital role of additives in enhancing the physiochemical of feed material and highlighted the effect of additives on spray drying efficiency in respect to its process parameters. Studies advances have shown that additives have improved significantly on products feed characteristic; lower moisture content, higher process yield, and powder flowability. Further research has shown a combination of additives enhances certain properties of feed material. The study signified the effect of additives as a vital role in improving the physicochemical properties of spray-dried powder. The difficulties of achieving powder specification demands can be resolved, by understanding and utilize the knowledge of additives on processing parameter of spray drying.
\end{abstract}

\section{Introduction}

The demand in the modern food industry is towards longer shelf life and product variations; leading to quality innovation in food engineering. The increasing world population and prioritization of food safety has led researchers on an alternative approach in food preservation. A conventional method, spray drying, has gained back recognition in fulfilling those demands. Its importance is emphasized on low operational expenditures in comparison to other heating method, specifically eight times more economical than freeze drying and four times more economic than vacuum drying (Rodríguez-Hernández et al., 2005). Spray drying is a drying method that produces droplets of liquid feed into powdered products. The conversion involved atomization of liquid feed, undergoes heat treatment to reduce its moisture content to the desired level (Master, 1991; Sivarajalingam, 2009; Shabde et al., 2010). The capability of spray drying enveloped on its high nutrient and flavour retention with rapid moisture evaporation during the conversion of liquid feed material into dried powdered form, leading to high powder stability and resistant to microbiological and oxidative degradation (Sagar and Suresh Kumar, 2010; Tan et al., 2011).

Commercialization value of spray drying process often valued many criteria; process yield, end product characteristic and production cost but has faced many setbacks in achieving high efficiency in those areas. The economic standpoint of using spray drying is high production cost and hygienic processing condition has led to the discovery of new attributes and findings in spray drying processes (Maa et al., 1998). One of many significant discoveries, process yield is a highly demanded trait in commercial spray drying production, likewise in food and pharmaceutical production. The complication that often diminished the process yield is the low glass transition temperature of feed material, usually found in fruit juice and high acidic feed material (Shishir and Chen, 2017). The nature of these liquid feed material tends to have lower molecular weight as sugars 
and acid, which have low glass transition temperature $\left(\mathrm{T}_{\mathrm{g}}\right)$ (Dolinsky, 2001; Chegini and Ghobadian, 2005; Wang and Zhou, 2013a). As a result, a stickiness problem is caused during spray drying, with the feed materials forming paste-like soft structure at the wall of the spray dryer. Adding additives during spray drying production have been an alternative choice for commercial producers to improve the stickiness problem.

Multiple researches have been done on various additives on process parameter and the properties of spray dried products (Goula and Adamopoulos, 2003; Namaldi et al., 2006; Vehring et al., 2007). However, there is lacking review papers on providing deep insight on the performances of various additives used on the physio-chemical properties of the powders (More Swati and Wagh, 2014; Shishir and Chen, 2017). This review paper provides a beneficial apprehensive knowledge on additives in spray drying performances.

\section{Type of additives}

The properties of additives for spray drying in use is critical, as it has an influence on the process parameter and physio-chemical properties of spray drying (Angel et al., 2009; Kha et al., 2010; Fang and Bhandari, 2012). A research has shown spray drying of blackberry powders using maltodextrin has higher significance loss of moisture content in comparison with other additives used (Ferrari et al., 2012). The combination of Arabic gum and maltodextrin used in spray drying of blackberry powder performed poorly compared to the prior additives. Similar results have shown on spray dried watermelon powder (Quek et al., 2007) and acerola powder (Righetto and Netto, 2005). Among commercially available additives that is used, major type additives that available for spray drying application are carbohydrates (hydrolysed starch, maltodextrin, dextran, cellulose and derived), gums (Arabic gums, agar, carrageenan), proteins (gluten, caseins, albumins, haemoglobin and peptides), lipid (wax, paraffin, diglycerides and peptides) and biopolymers. Spray drying application using lipid and biopolymers are less significant and a handful of journals has only discovered.

\subsection{Carbohydrates}

Commonly used carbohydrate-additives, maltodextrin are found in the form of white powder, made from corn starch hydrolysed by acids of enzymes. Maltodextrin is non-sweet, neutral smell additives and often used in spray drying production due to its low costing and bulking properties (Bae and Lee, 2008). The variable nature of maltodextrin can be found through the degree of hydrolysis of root starch polymer. The significant higher level of dextrose equivalent (DE) in the hydrolysed starch has lower average molecular weight and has low permeability to oxygen and water (Chegini and Ghobadian, 2005; Chiu et al., 2007; Ersus and Yurdagel, 2007). Similarly, studies were done by Bangs and Reineccius (1982) has stated that maltodextrin with dextrose equivalent between 10 and 20 have higher flavour retention. Otherwise, usage of lower DE with higher molecular weight has improved on the transition temperature of the product (Table 1), in respect to reducing lower product losses and caking problem (Goula and Adamopoulos, 2003).

Table 1. Relationship between DE, MW and $\mathrm{T}_{\mathrm{g}}$ of maltodextrin (Adapted from Roos and Karel (1991))

\begin{tabular}{ccc}
\hline Dextrose Equivalence & Molecular weight $(\mathrm{MW})$ & $\mathrm{T}_{\mathrm{g}}\left({ }^{\circ} \mathrm{C}\right)$ \\
\hline 36 & 500 & 100 \\
25 & 720 & 121 \\
20 & 900 & 141 \\
10 & 1800 & 160 \\
5 & 3600 & 188 \\
\hline
\end{tabular}

Maltodextrin as additives has a significant effect on the solubility of powder, however, has shown contradicting results in hygroscopicity properties of the powder. The concentration of maltodextrin has shown to produce higher hygroscopicity properties of green tea extract (Tengse et al., 2017) but lower hygroscopicity properties of cactus pear juice (Rodriguez-Hernandez et al., 2007) and betacyanin pigments (Cai and Corke, 2000). However, maltodextrin has low emulsifying capacity and studies have shown that a combination of maltodextrin with other additives significantly improved the quality of powdered products. Commonly known mixtures of maltodextrin with Arabic gum (Minemoto et al., 2002), modified starch (Loksuwan, 2007) and whey proteins (Wang and Zhou, 2013b) are shown to have immediate improved results compared to prior

Spray drying using sucrose $\left(62^{\circ} \mathrm{C}\right)$, glucose $\left(32^{\circ} \mathrm{C}\right)$ and fructose $\left(5^{\circ} \mathrm{C}\right)$ as additives are not suitable with high temperature of spray drying which can cause caramel caramelization. Prior additives stated causes low product yield and operational problem due to their low transition temperature (Bayram et al., 2005; Azadeh et al., 2010). Furthermore, the non-hydrophobic properties of starch have high viscosity value. Modified starch has found their way into commercial spray drying production, where modified starches have high retention of volatiles and stability. However, maltodextrin is commonly added with modified starches to improve against oxidation during stocking (Krishnan et al., 2005). Studies on cellulose as a stand-alone additive for spray drying has not been found in recent years. However, cellulose has been used as complementary additives in spray drying of mango juice (Cano-Chauca et al., 2005) and soy sauce (Wang and Zhou, 2015). Adding cellulose as drying aid 
produces partial crystalline surface, reduce stickiness and caking problem (Fazaeli et al., 2013).

The nature of carbohydrate-additives that has high molecular weights helped to increase the transition temperature of the spray drying process. As the rapid removal of water molecular during the process of spray drying produces amorphous material, in resultant of surface stickiness between adjacent powder particles. The caking problem occurred as the surface viscosity has reached a critical value and formation of inter-particle bonds between particle. The root cause of this situation is often seen in spray drying of sugar and acid-rich foods, such as fruit juice (Goula and Adamopoulos, 2010; Kha et al., 2010). Wang and Zhou (2013a) have suggested using a combination of maltodextrin-cellulose additives to overcome this problem as cellulose is correlated with decreased of stickiness.

\subsection{Protein}

The usage of protein as spray drying additives such as gelatin, casein, whey protein concentration (WPC) and skimmed milk powder (SMP) (Yoshii et al., 2001; Rao, 2002; Shi et al., 2013) has shown that preference for using protein additives has increased over time in relation to multiple researches on multiple feed products. The differentiation between protein and other spray drying additives is the ability of protein additives to combine with a different type of feed products through their molecular chain diversity and functional properties. Protein additives have rapid film-forming properties, large molecular weight and expanded functional properties such as high solubility and viscosity. These attributes render protein of capable spray drying additives similar to maltodextrin and gums. Furthermore, the usage of proteins has shown to improve significantly on spray drying of high sugar content powder (Jayasundera et al., 2011).
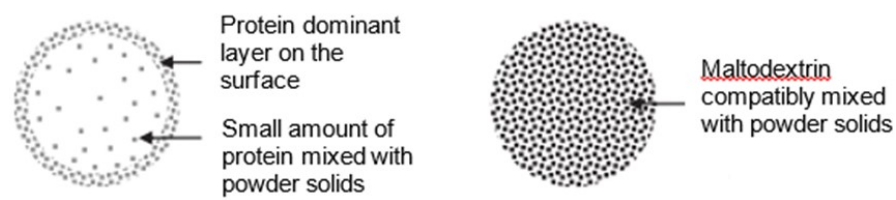

Figure 1. Illustration of spray dried powder particle with addition of protein (left) and maltodextrin (right)

Small concentration of protein additives added is capable of forming film properties around the surface spray-dried particles, prompting a thin protein-rich film to resist particle-to-particle cohesive and particle-to-wall stickiness as illustrated in Figure 1. Faldt et al. (1993) have also discovered that the additional of small amount of protein in spray drying of honey has maintained the bulk composition and improved the quality of the spray- dried honey properties. Adhikari et al. (2009) have discovered that addition of protein increase powder production but discovered that doubling the concentration of protein additive does not increase the spray drying yield.

On the same study line, casein, a type of protein additives, has shown to improve product yield and crystallization delay of lactose. In contrast, a study done by Wang et al. (2010) has shown that at a certain concentration of casein, the crystallization process of lactose-casein powder is delayed. The significant of both studies have shown that high-protein concentration powders have substantially different structure and stability compared to low-protein concentration powders, considering the type of protein-additives and concentration of feed-additives (Tzannis and Prestrelski, 1999). Whey powder has the capability of retaining flavouring compound of high acidity of fruit powder such as sumac berries, however, additives like milk powder and guar gum were unable to achieve significant expected results (Bayram et al., 2007).

Common usages of protein additives in spray drying are milk protein and gelatines. For instance, Young et al. (1993) have discovered that spray drying efficiency and preservation of milk fat yield is greater comparing without the use of additives. New studies have found that vegetable proteins-additives have additional functional advantages (biocompatibility, biodegradability, emulsifying (More Swati and Wagh, 2014) and foaming capacity) compare its counterparts, commercial protein-additive. However further research is required to utilize vegetable protein as a part of commercially available additives (Nesterenko et al., 2013).

\subsection{Gums}

Among all gums, acacia gum (Arabic) is the most commonly used gum-additives for spray drying. This additive is widely used due to its excellent emulsification properties as acacia gums consist of a combination of complex carbohydrates and protein (D-glucuronic acid, L-rhamnose, D-galatose and L-arabinose in the proportion of 4:2:2:1) (Swenson et al., 1968). The protein component of the acacia gum improves the emulsification properties (Dickinson, 2003; RománGuerrero et al., 2009). Similar to maltodextrin and protein, gum Arabic is ideally suitable because of its surface activity and film form activity. Acacia gum, however, has a wider range of $\mathrm{pH}$ range in producing stable emulsions, making acacia gum an exceptional additive for lipid-based powdered products (Minemoto et al., 2002). The usage of soluble fibre and gum acacia helped improved probiotic viability (Lactobacillus 
paracasei) during the spray drying of milk, whereas spray drying of high sugar feed like pomegranate juice using acacia gums has a higher yield and is proven to be effective in compared to other carrier-additives. Abadio et al. (2004) and Goula and Adamopoulos (2005) have stated that powdered product spray dried with acacia gum does not have crystalline configuration and lower bulk density is observed as related to the powder. Despite its calibre, the usage of Arabic gum is associated with high cost, limited availability and impurities due to prone to variability in supply and quality.

\section{Properties of additives}

The selection choice of additive for spray drying has to be reflected on the physio-chemical properties of the additives itself. Such criteria as molecular weight, glass transition, the concentration of additives are to be considered in additives selection (Table 2). Moreover, the type of feed material used together with added additives has a significant impact on the properties performance (Gharsallaoui et al., 2007). Therefore, considerations of additives choice according to the desired application required tedious knowledge application of spray drying.

\subsection{Molecular weight of additives}

The molecular weight of additives represents the molecular size of the additives itself, plays a major role in spray drying enhancement. The molecular weight has a direct relationship with transition temperature, in which shorter chain molecules of additives have low transition temperature than longer chain of additives (Goula and Adamopoulos, 2003; Shrestha et al., 2007; Adhikari et al., 2009). Bhandari et al. (1997) have stated that comparing maltodextrin (DE 36) with a molecular weight of 500 and transition temperature of $100^{\circ} \mathrm{C}$, with maltodextrin (DE 5) that has a significantly higher transition temperature of $188^{\circ} \mathrm{C}$. Furthermore, increasing transition temperature contribute to powder stability and reduce caking and stickiness problem. Gum acacia has higher molecular weight in comparison to maltodextrin. As the transition temperature increase with the increase in molecular weight, the addition of gum acacia (Arabic) has a higher $\mathrm{T}_{\mathrm{g}}$ compared to the addition of maltodextrin (Pedroza-Islas et al., 1999).

The concentration of DE determined the spray dried product yield. (Samborska, Gajek, and KamińskaDwórznicka, 2015). Papadakis et al. (2006) and Samborska et al. (2015) found that increasing DE of maltodextrin improved significantly on product yield of dry raisin juice and honey bee. The discovered trend can be shown by the difficulty of smaller molecules of water diffusing in between large chain of maltodextrin. Large chain of molecules has high molecular weight of additives that affect other properties as well. Corke (2000) has discovered that as the molecular weight of maltodextrin decreased, the hydroscopicity of amaranthus betacyanin pigments increased. The author has stated that the molecular configuration of shorter chain maltodextrin has more hydrophilic groups. This is also supported by research done on spray dried acai pulp (Tonon et al., 2008) with similar results. Taylor et al. (2008) have stated that the larger molecular weight of maltodextrin has a direct relationship with faster rehydration and reabsorption of powdered particles, due to the higher surface area over volume ratio exposed to moisture.

\subsection{Concentration of additives}

One of the most important factor to improve physiochemical properties of feed materials is the concentration of additives used for spray drying. High concentration additives used in feed material produce a difference in the yield percentage, transition temperature, hydroscopicity and other physico-chemical properties. Studies have shown that an increase of maltodextrin percentage used in spray drying of orange juice concentrate results in yield percentage (Shrestha et al., 2007). However, the author has stated that a level of maltodextrin is required to produce a significant result of spray drying. Similar results have shown by spray drying of mixture of pineapple and maltodextrin, by which the recovery of feed solids in the product has improved (Abadio et al., 2004). In general, multiple published paper has shown that increase of maltodextrin concentration has resulted in an increase of yield product percentage (Gonnissen et al., 2008; Mishra et al., 2014; Avila et al., 2015). The yield product percentage can be supported by the fact that surplus level of maltodextrin increases the total solid and reduced the level of total water for evaporation (Jangam and Thorat, 2010; Mestry et al., 2011; Horuz et al., 2012).

The superiority of maltodextrin in water solubility led to the fact that higher concentration of additives added produces powder with lower moisture content (Khalilian Movahhed and Mohebbi, 2016). However, the concentration of maltodextrin added does not affect its rehydration ability to absorb moisture. (Cano-Chauca et al., 2005; Grabowski et al., 2006). Similarly, the concentration of protein additives has inconsistent results towards physiochemical properties of spray dried powder. Addition of protein additives at certain concentration increase yield production but doubling the concentration yield insignificant results (Adhikari et al., 2009). The ratio of protein-carbohydrate additives has proven contradicting results in term crystallization 


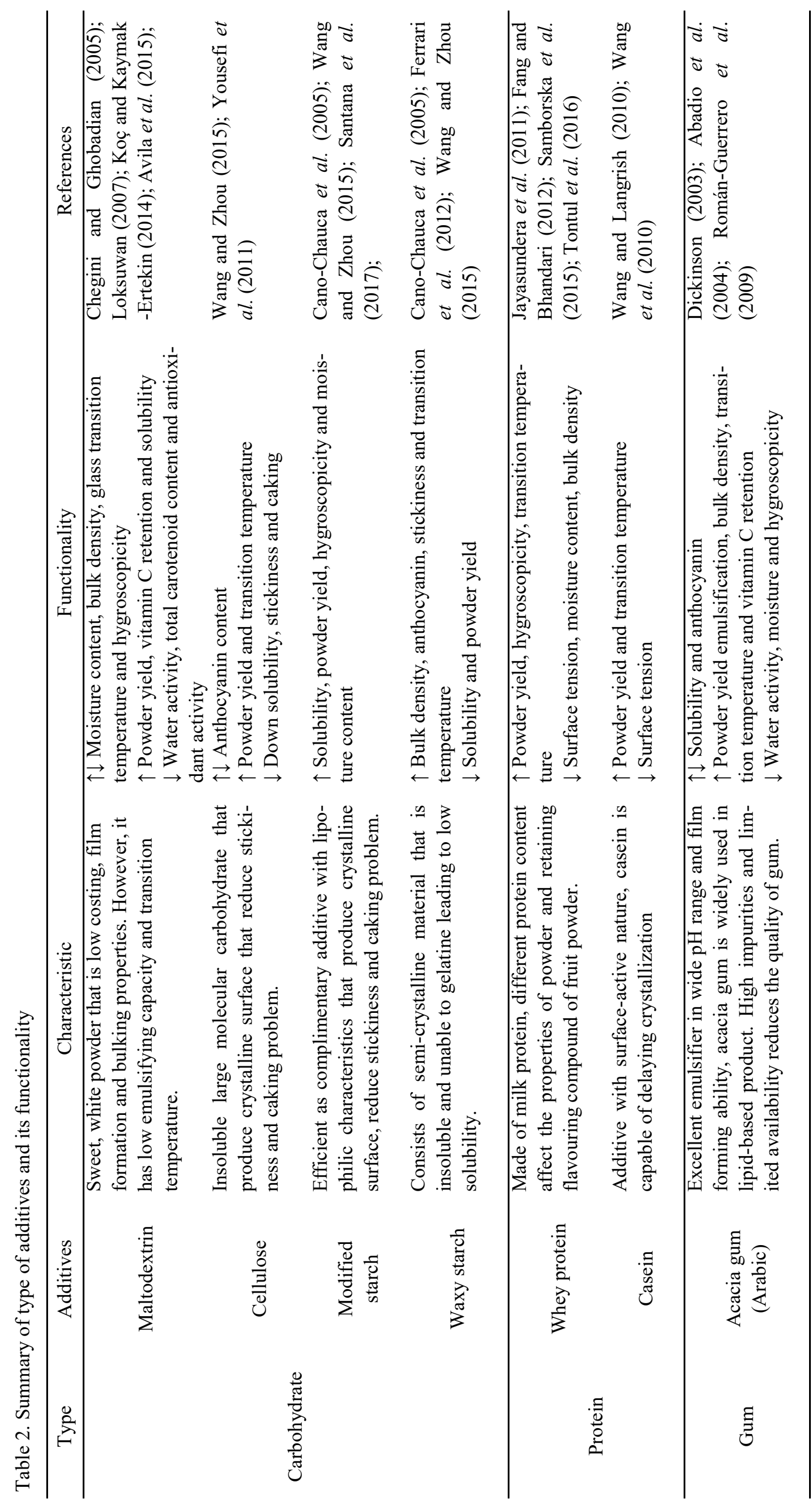


process (Wang and Langrish, 2010).

\subsection{Suitability of spray drying feed}

The type of feed materials has a significant impact on the efficiency of the additives used. As the type of feed materials has board comparison in properties (sugar and fat content, viscosity, and transition temperature), understanding on the spray drying of feed has to be included on its wide range of processing parameter with an in-depth quality parameter of the powder attained (Wang and Langrish, 2009). One of the qualities that can be achieved as according to Bhandari et al. (1997), powder recovery greater than $50 \%$ is stated to be an efficient spray drying system.

Commonly used additives such as maltodextrin, gum acacia, and whey protein concentrate are used to test as the comparison on different type of food production. The selection of additives is heavily supported by understanding the properties of both spray drying feed and the additives used, as different additives have different physical and chemical structure. Gum acacia is a highly ramified structure that contains shorter chains and hydrophilic groups, while protein additives have many different functional advantages such as biocompatibility, biodegradability, emulsifying and foaming capacity, water and fat absorption, gelation and film-forming properties (Nesterenko et al., 2013).

The challenge of feed selection is also hindered by the complexity of spray drying operating parameters on the physio-chemical properties of the powder. Comparison of performance between the maltodextrin and soy protein isolate (SPI) on spray dried tamarin pulp powder has emphasized on its powder quality (Muzaffar and Kumar, 2016). The increasing level of maltodextrin increases both the moisture content and $a_{w}$ of the tamarind pulp powder, while the increase used of SPI has shown otherwise, with an increased level of moisture content but lower $\mathrm{a}_{\mathrm{w}}$. However, at high level of both maltodextrin and SPI, the moisture content of the powder decreased. Inconsistent trend data are also found on the study of blackberry powder (Ferrari et al., 2012), chicken meat protein hydrolysate (Kurozawa et al., 2009), acerola powder (Righetto and Netto, 2005) and tomato juice powder (Tontul, Topuz, Ozkan, and Karacan, 2016).

Based on the researches published, there is a lack of viable and reliable results showing a comparison of performance between the commercially available additives. Anandharamakrishnan et al. (2007) and Gharsallaoui et al. (2007) have stated that understanding the process spray drying requires trial-and-error method as it involves a multitude of factors.

\section{Influence of additives on properties changes in dried powder product}

\subsection{Bulk density}

Recent researches have shown that there is no clear relationship between additives capabilities and bulk density. Additives addition into feed solution has a different effect on the bulk density. Due to the capabilities of maltodextrin as a carrier and coating agent, its application is widely used on the spray drying of betacyanin pigment (Cai and Corke, 2000), beetroot powder (Singh and Hathan, 2017). Addition of maltodextrin additive effect the changes the bulk density of powdered particles. This is proven by the fact that skin forming nature of maltodextrin increases the volume of air trapped in the particle and reduce thermoplasticity. Kwapinska and Zbicinski (2005) has shown that additives with skin-forming properties like maltodextrin often contained air bubbles, in which increasing used of similar additives, the lower the bulk density of powders.

Application of gum acacia (Arabic) in spray drying has exhibited similar results, as acacia gum (Arabic) has a higher $\mathrm{Tg}$ point by its large molecule size. Furthermore, this is supported by the fact that additives of increasing concentration, the bulk density of orange juice powder have proven to decrease (Shrestha et al., 2007). In contrast, multiple reports done by Abadio et al. (2004) and Yousefi et al. (2011) tomato juice and pineapple pulp have shown opposite results. They have stated that as additive concentration increases, the bulk density of powder decreased. The supported fact added by the authors is that the particle size of powder increased as the concentration of additive increase.

\subsection{Glass transition}

Glass transition temperature $(\mathrm{Tg})$ is a property of an amorphous material, where it defined as the temperature of product amorphous system interchanging between a glassy and a rubbery state. Usually, food products that formed in a rapid heat exchanging environment process, are not at thermodynamic equilibrium. They will undergo the transition from a glassy crystalize temperature to rubbery state matter depending on their water activity level and molecular weight. Similarly, transition temperature $(\mathrm{Tg})$ is highly associated with changes in various physical properties such as boiling and melting point and appearances. Increasing temperature above $\mathrm{Tg}$ of a material increase rate of deteriorative, stickiness, collapsing and crispness, as molecular mobility and viscosity exponentially increases (Roos and Karel, 1991).

In this context, spray drying of pure fruit juice into powdered form faced similar difficulty as fruits juice consists of low-molecular weight molecules such as 
sucrose, glucose, fructose, and malic and citric acids, which cause a stickiness problem during spray drying. The stickiness is attributed to the low transition temperature of sugar molecules, as summarized in Table 3 (Fang and Bhandari, 2012; Du et al., 2014). Similarly, spray drying of organic acid and solution poses similar difficulties.

Table 3. Glass transition temperature $\mathrm{T}_{\mathrm{g}}$, of different materials.

\begin{tabular}{lcl}
\hline Material & $\begin{array}{c}\text { Glass } \\
\text { transition } \\
\text { temperature } \\
\left({ }^{\circ} \mathrm{C}\right)\end{array}$ & \multicolumn{1}{c}{ References } \\
\hline Galactose & 30 & Roos $(2002)$ \\
Glucose & 31 & Roos $(2002)$ \\
Lactose & 101 & Roos (2002) \\
Ascorbic acid & 58 & Da Róz et al. (2011) \\
Citric acid & 58 & Da Róz et al. (2011) \\
Fructose & 16 & Jouppila and Roos (1994) \\
Maltose & 87 & Jouppila and Roos (1994) \\
\hline
\end{tabular}

To overcome low glass transition temperature of feed material, adding additives have shown to increase the molecular weight of molecules, therefore increasing feed's transition temperature. By this application, the extension of shelf life of the powder can be extended. High stability of powder is associated with high transition temperature and the risk of caking, powder collapse and crystallization can be reduced (Khalilian Movahhed and Mohebbi, 2016; Kurozawa et al., 2009).

\subsection{Particle size}

The size of particle formed during spray drying is strongly related to feed viscosity, as higher liquid viscosity, the larger the droplets formed during atomization produces larger particles obtained during spray drying (Jinapong et al., 2008). Similarly, in a spray drying process, Keogh et al. (2003) have found that there an increase in particles size based on an increase in feed viscosity of ultra-filtered whole milk concentrated. The addition of additives, especially an increase of maltodextrin concentration has proven to increase the particle size of spray dried powder. Goula and Adamopoulos (2005) emphasized the addition of maltodextrin caused an increase of viscosity and produced slurry dry matter in the solution, leading to large powder production. The results produced by the authors are aligned with the results reported by Kurozawa et al. (2009) on chicken meat hydrolysate powder and Tonon et al. (2008) on acai powder. Nevertheless, no studies have been found on protein and other similar additives producing any implication on the size of particle powder. The authors have stated that this may due to the fact that protein additives and other additives do not have the viscosity-changing ability as compared to maltodextrin.

\subsection{Colour index}

The physical appearance of spray dried powder is highly valued, as colour and texture of the powder are highly perceived by consumers. The additional of additives can maintain or disintegrate the physical appearance of the powders especially the colour index, depending on the type of feed material and concentration of additives used (Grabowski et al., 2006).

As the function of additives used in spray drying may increase the droplet size of atomized feed as viscosity increases, there are no reports stating that additives improved the physical appearance of end powder products. Otherwise, the increase concentration of maltodextrin diluted the colour of the feed solution and the end product significantly as maltodextrin is usually bright white in natural form (Du et al., 2014).

Furthermore, reports have stated that atomization of feed solution into tiny droplets has increase surface area exposed to rapid pigment oxidation, leading to lower $\mathrm{a} / \mathrm{b}$ value and high hue angle (Desobry et al. 1997). Abadio et al. (2004) have suggested that adding maltodextrin with concentration up to $15 \%$ did not affect the appearance of the powder solution. Overall, there are insufficient studies done on the effect of additives on the powder colour index, as major studies focused on yield production, moisture content and other parameters.

\subsection{Solubility index}

A key determinant of the powder quality, solubility is an important key factor for evaluating wettability and dispersibility of powder in aqueous solution. The solubility index of spray dried powder is affected by the raw materials and additives used, and also the properties of the powder (moisture content and size of particles). Literature reviews have stated that the functionality of maltodextrin gave arose on the explanation of the increase of solubility of powder with increase of additives used. Crust formation occurred during rapid heat exchange environment in the chamber, where the least soluble substance started to precipitate and forming crust at the droplet surface. Therefore, the formed crust is mainly constituted of maltodextrin that is highly soluble in nature. Similar authors have found this fact aligned with their research such as Goula and Adamopoulos (2008) on tomato pulp powder, Grabowski et al. (2006) on sweet potato puree powder and Caliskan and Nur Dirim (2013) on sumac extract powder. 
On the contrary, studied on spray drying on tea leaves extract using maltodextrin does not have a significant effect on the solubility of powder (Quek et al., 2007). The authors have suggested that a hard surface layer might have formed over the powder particle, preventing the diffusion of water molecules. Therefore, the wettability and solubility of the particle are reduced. Based on the two observations, additives in spray drying produced opposing and contradicting results in the observance of powder solubility. Overall, a summarized of main findings based on type of carriers and feed material is shown in Table 4.

\section{Effect of additives on spray drying parameters optimization}

Certain criteria have taken under concern regarding powder production using the application spray drying required high energy consumption, leading to high operational costs due to the rapid heat exchanging process. Added to that, optimization of spray drying requires an evaluation of both spray drier parameter and feed formulation, as the modulating of spray drying must be controlled to avoid low yield, moisture content and sticking problem (Oakley, 2004; Nekkanti et al., 2009; Aghbashlo et al., 2015;).

Multiple reports have stated that effective additives can optimize the performance of spray drying parameters. The efficiency of spray drying parameters such as inlet temperature, feed flow rate, outlet temperature and nozzle pressure can be enhanced with the use of additives. Furthermore, the use of additives is cost reducing and high productivity through the functionality of additives of manipulating the transition temperature, total soluble solids and viscosity of the solution (Yousefi et al., 2011; Lee et al., 2017; Santana et al., 2017).

In the spray drying of sumac extracts, an increase of maltodextrin concentration extended the feed flow rate of sumac extracts, leading to improved yield powder product percentage. The addition of maltodextrin additives increases the total soluble solids (TSS) content, resulted in an increase in efficiency yield (Caliskan and Nur Dirim, 2013). Despite that, the addition of additives has its own setbacks. Addition of large maltodextrin molecules as additives in a spray drying operation led to a less efficient system, where high residual moisture content found in powder products. Goula and Adamopoulos (2005) concluded that in a rapid heat exchanging system, water molecules have difficulty in escaping from maltodextrin due to their large size and film coating abilities. Furthermore, the increase of additives would produce a higher viscosity feed which reduces the product yield of powder (Tonon et al., 2008).
Based on the author research, the increase of TSS through the addition of additives decrease the yield percentage.

Similarly, the relationship of maltodextrin and inlet air temperature showed a negative correlations relationship towards water activity. The powder water activity can be greatly reduced by the addition of maltodextrin. However, there is no proven fact that the inlet air temperature required to produce powder at a specific water activity can be reduced by the addition of maltodextrin additives (Cai and Corke, 2000; Quek et al., 2007; Shavakhi et al., 2012). Overall, a handful of reports has been published on the effectiveness of additives of spray drying optimization, in which there is no clear linear relationship between additives and spray drying parameters has been identified.

\section{Conclusion}

Based on the published reports that signified the effect of additives on the properties of the powder, it is shown that different food powder has shown different characteristic under the influence of different additives. However, a similar trait has appeared that emphasized on the main function of additives; additives improve product yield through the manipulation of transition temperature. Added to that, usage of combination additives proved positive results towards better yield, solubility and bulk density.

The lack of research on additives is towards the microscopic point of view, where there are substantial evidence showing how the additives reacted on different powders products. The functionality of additives reacted different towards a similar group product but has shown contradicting and opposing results (More Swati and Wagh, 2014; Shishir and Chen, 2017). High sugar content fruit juices are a few of those examples.

Spray drying is an extensive research drying process that is applied to many food ranges of products. This review paper that focuses on additives has shown its capabilities and potentials in enhancing powder properties through incorporation with the spray drying processing parameters. Further research on additives is likely to improve on the efficiency of spray drying.

\section{Acknowledgement}

The author is grateful to those who have contributed to this review paper. (No Vot. 9498700) 
Table 4. Summary of main findings done on type of carrier and feed material

\begin{tabular}{|c|c|c|c|}
\hline Feed material & Type of carrier & Main findings & References \\
\hline Pomegranate Juice & $\begin{array}{l}\text { Maltodextrin } \\
(\mathrm{DE} 20) \text { arabic } \\
\text { gum, and waxy } \\
\text { starch }\end{array}$ & $\begin{array}{l}\text { Arabic gum produced highest yield than other carriers; with } \\
\text { lowest bulk density and particle size } \\
\text { Colour and anthocyanin of pomegranate juice is efficient with } \\
\text { maltodextrin }\end{array}$ & $\begin{array}{l}\text { Yousefi et al. } \\
(2011)\end{array}$ \\
\hline $\begin{array}{l}\text { Babassu coconut } \\
\text { milk }\end{array}$ & $\begin{array}{l}\text { Maltodextrin and } \\
\text { modified starch }\end{array}$ & Modified starch outperformed maltodextrin in product recovery & $\begin{array}{l}\text { Santana et al. } \\
(2017)\end{array}$ \\
\hline Acai Pulp & Maltodextrin & $\begin{array}{l}\text { Addition of maltodextrin has negative effect on yield and } \\
\text { powder hygroscopicity }\end{array}$ & $\begin{array}{l}\text { Tonon et al. } \\
(2008)\end{array}$ \\
\hline $\begin{array}{l}\text { Cashew apple } \\
\text { juice }\end{array}$ & $\begin{array}{l}\text { Cashew tree gum } \\
\text { and maltodextrin }\end{array}$ & $\begin{array}{l}\text { Combination of cashew tree gum and maltodextrin improved } \\
\text { the physical properties of powder }\end{array}$ & $\begin{array}{l}\text { De Oliveira et } \\
\text { al. }(2009)\end{array}$ \\
\hline $\begin{array}{l}\text { Chicken meat } \\
\text { protein } \\
\text { hydrolysate }\end{array}$ & $\begin{array}{l}\text { Maltodextrin } \\
\text { (DE10) and gum } \\
\text { Arabic }\end{array}$ & $\begin{array}{l}\text { The increase concentration of maltodextrin and gum Arabic } \\
\text { both reduces moisture content, hygroscopicity and increase } \\
\text { transition temperature }\end{array}$ & $\begin{array}{l}\text { Kurozawa et al. } \\
\text { (2009) }\end{array}$ \\
\hline $\begin{array}{l}\text { Sweet potatoes } \\
\text { puree }\end{array}$ & $\begin{array}{l}\text { Maltodextrin } \\
\quad(\mathrm{DE} 11)\end{array}$ & $\begin{array}{l}\text { Increase of maltodextrin reduces moisture content and increase } \\
\text { solubility index and transition temperature }\end{array}$ & $\begin{array}{l}\text { Grabowski et al. } \\
(2006)\end{array}$ \\
\hline $\begin{array}{l}\text { Amaranthus } \\
\text { betacynin } \\
\text { pigments }\end{array}$ & $\begin{array}{l}\text { Maltodextrin } \\
(\mathrm{DE} 10-\mathrm{DE} 25)\end{array}$ & $\begin{array}{l}\text { The combination of highest (DE25) and lowest (DE10) has } \\
\text { highest betacynin retention. }\end{array}$ & $\begin{array}{l}\text { Cai and Corke } \\
(2000)\end{array}$ \\
\hline Pumpkin & Maltodextrin & $\begin{array}{l}\text { Higher maltodextrin concentration produced lower yield even } \\
\text { though has higher transition temperature and hygroscopicity }\end{array}$ & $\begin{array}{l}\text { Shavakhi et al. } \\
(2012)\end{array}$ \\
\hline Carrot-celery juice & Maltodextrin & $\begin{array}{l}\text { Increase of maltodextrin concentration reduced moisture } \\
\text { content, water activity, hygroscopicity, } \beta \text {-carotene and bulk } \\
\text { density, while increase particle size and dissolution time. }\end{array}$ & $\begin{array}{l}\text { Khalilian } \\
\text { Movahhed and } \\
\text { Mohebbi } \\
(2016)\end{array}$ \\
\hline $\begin{array}{l}\text { Tamarind pulp } \\
\text { powder }\end{array}$ & $\begin{array}{l}\text { Maltodextrin } \\
(\mathrm{DE} 20) \text {, gum } \\
\text { arabic and whey } \\
\text { protein }\end{array}$ & $\begin{array}{l}\text { Whey protein outperformed maltodextrin and gum Arabic in } \\
\text { powder recovery, bulk density and good flowability. }\end{array}$ & $\begin{array}{l}\text { Bhusari et al. } \\
\text { (2014) }\end{array}$ \\
\hline Soy sauce & $\begin{array}{l}\text { Maltodextrin and } \\
\text { whey protein }\end{array}$ & $\begin{array}{l}\text { Combination of whey protein }(>5 \%) \text { into soy sauce- } \\
\text { maltodextrin solution increased product yield by } 20 \% \text {. Adding } \\
\text { whey protein delay caking problem. }\end{array}$ & $\begin{array}{l}\text { Wang et al. } \\
(2013)\end{array}$ \\
\hline Pineapple juice & Maltodextrin & $\begin{array}{l}\text { Increase in maltodextrin reduces the true density and moisture } \\
\text { content of powder }\end{array}$ & $\begin{array}{l}\text { Abadio et al. } \\
(2004)\end{array}$ \\
\hline Honey & $\begin{array}{l}\text { Maltodextrin and } \\
\text { whey protein }\end{array}$ & $\begin{array}{l}\text { Powder recovery }(>50 \%) \text { are achieved when maltodextrin and } \\
\text { whey protein used in combination and separately }\end{array}$ & Shi et al. (2013) \\
\hline Blackberry juice & $\begin{array}{l}\text { Maltodextrin } \\
\text { Gum Arabic }\end{array}$ & $\begin{array}{l}\text { Maltodextrin outperformed gum Arabic in lower moisture } \\
\text { content, higher anthocyanin retention and oxidant activity }\end{array}$ & $\begin{array}{l}\text { Ferrari et al. } \\
(2012)\end{array}$ \\
\hline $\begin{array}{l}\text { Raisin juice } \\
\text { concentrate }\end{array}$ & $\begin{array}{l}\text { Maltodextrin } \\
(\mathrm{DE} 6,12 \text { and } 21)\end{array}$ & $\begin{array}{l}\text { Lower DE of maltodextrin reduces the temperature of inlet } \\
\text { drying air for successful powder production. }\end{array}$ & $\begin{array}{l}\text { Papadakis et al. } \\
\text { (2006) }\end{array}$ \\
\hline Beetroot Juice & $\begin{array}{l}\text { Maltodextrin }(20 \text {, } \\
25 \text { and } 30 \%)\end{array}$ & $\begin{array}{l}\text { The increase of maltodextrin concentration resulted in lower } \\
\text { moisture content }\end{array}$ & $\begin{array}{l}\text { Singh and } \\
\text { Hathan (2017) }\end{array}$ \\
\hline
\end{tabular}

\section{References}

Abadio, F.D.B., Domingues, A.M., Borges, S.V. and Oliveira, V.M. (2004). Physical properties of powdered pineapple (Ananas comosus) juice - Effect of malt dextrin concentration and atomization speed. Journal of Food Engineering, 64(3), 285-287. https://doi.org/10.1016/j.jfoodeng.2003.10.010

Adhikari, B., Howes, T., Bhandari, B.R. and Langrish, T.A.G. (2009). Effect of addition of proteins on the production of amorphous sucrose powder through spray drying. Journal of Food Engineering, 94(2), 144-153. https://doi.org/10.1016/ j.jfoodeng.2009.01.029

Aghbashlo, M., Hosseinpour, S. and Mujumdar, A.S. (2015). Application of Artificial Neural Networks (ANNs) in Drying Technology: A Comprehensive Review. Drying Technology, 33(12), 1397-1462. https://doi.org/10.1080/07373937.2015.1036288

Anandharamakrishnan, C., Rielly, C.D. and Stapley, A.G.F. (2007). Effects of Process Variables on the 
Denaturation of Whey Proteins during Spray Drying. Drying Technology, 25(5), 799-807. https:// doi.org/10.1080/07373930701370175

Angel, R.C.M., Espinosa-Muñoz, L.C., Aviles-Aviles, C., González-García, R., Moscosa-Santillán, M., Grajales-Lagunes, A. and Abud-Archila, M. (2009). Spray-drying of passion fruit juice using lactosemaltodextrin blends as the support material. Brazilian Archives of Biology and Technology, 52 (4), 1011-1018. https://doi.org/10.1590/S151689132009000400026

Avila, E.L., Rodríguez, M.C. and Velásquez, H.J.C. (2015). Influence of Maltodextrin and Spray Drying Process Conditions on Sugarcane Juice Powder Quality. Revista Faculted Nacional de Agronomia, 68(1), 7509-7520. https://doi.org/10.15446/ rfnam.v68n1.47839

Azadeh, A., Neshat, N. and Saberi, M. (2010). An intelligent approach for improved predictive control of spray drying process. In 2010 IEEE 14th International Conference on Intelligent Engineering Systems, 5 - 7 May 2010, p. 127-136. Spain: IEEE. https://doi.org/10.1109/INES.2010.5483859

Bae, E.K. and Lee, S.J. (2008). Microencapsulation of avocado oil by spray drying using whey protein and maltodextrin. Journal of Microencapsulation, 25(8), 549-560. https:// doi.org/10.1080/02652040802075682

Bangs, W.E. and Reineccius, G.A. (1982). Influence of Dryer Infeed Matrices on the Retention of Volatile Flavor Compounds During Spray Drying. Journal of Food Science, 47(1), 254-259. https:// doi.org/10.1111/j.1365-2621.1982.tb11072.x

Bayram, O.A., Bayram, M. and Tekin, A.R. (2007). Whey Powder As a Carrier in Spray Drying of Sumac Concentrate. Journal of Food Process Engineering, 31(1), 105-119. https:// doi.org/10.1111/j.1745-4530.2007.00168.x

Bayram, Ö.A., Bayram, M. and Tekin, A.R. (2005). Spray drying of sumac flavour using sodium chloride, sucrose, glucose and starch as carriers. Journal of Food Engineering, 69(2), 253-260. https://doi.org/10.1016/j.jfoodeng.2004.08.012

Bhandari, B.R., Datta, N. and Howes, T. (1997). Problems Associated With Spray Drying Of SugarRice Foods. Drying Technology, 15(2), 671-684. https://doi.org/10.1080/07373939708917253

Bhusari, S.N., Muzaffar, K. and Kumar, P. (2014). Effect of carrier agents on physical and microstructural properties of spray dried tamarind pulp powder. Powder Technology, 266, 354-364. https:// doi.org/10.1016/j.powtec.2014.06.038
Cai, Y.Z. and Corke, H. (2000). Production and Properties of Spray-dried Amaranthus Betacyanin Pigments. Journal of Food Science, 65(7), 12481252. https://doi.org/10.1111/j.13652621.2000.tb10273.x

Caliskan, G. and Nur Dirim, S. (2013). The effects of the different drying conditions and the amounts of maltodextrin addition during spray drying of sumac extract. Food and Bioproducts Processing, 91(4), 539-548. https://doi.org/10.1016/j.fbp.2013.06.004

Cano-Chauca, M., Stringheta, P.C., Ramos, A.M. and Cal-Vidal, J. (2005). Effect of the carriers on the microstructure of mango powder obtained by spray drying and its functional characterization. Innovative Food Science and Emerging Technologies, 6(4), 420 -428. https://doi.org/10.1016/j.ifset.2005.05.003

Chegini, G.R. and Ghobadian, B. (2005). Effect of spraydrying conditions on physical properties of orange juice powder. Drying Technology, 23(3), 657-668. https://doi.org/10.1081/DRT-200054161

Chiu, Y.T., Chiu, C.P., Chien, J. T., Ho, G.H., Yang, J. and Chen, B.H. (2007). Encapsulation of Lycopene Extract from Tomato Pulp Waste with Gelatin and Poly $(\gamma$-glutamic acid) as Carrier. Journal of Agricultural and Food Chemistry, 55(13), 51235130. https://doi.org/10.1021/jf0700069

Da Róz, A.L., Zambon, M.D., Curvelo, A.A.S. and Carvalho, A.J.F. (2011). Thermoplastic starch modified during melt processing with organic acids: The effect of molar mass on thermal and mechanical properties. Industrial Crops and Products, 33(1), 152-157. https://doi.org/10.1016/ j.indcrop.2010.09.015

De Oliveira, M.A., Maia, G.A., De Figueiredo, R.W., De Souza, A.C.R., De Brito, E.S. and De Azeredo, H.M.C. (2009). Addition of cashew tree gum to maltodextrin-based carriers for spray drying of cashew apple juice. International Journal of Food Science and Technology, 44(3), 641-645. https:// doi.org/10.1111/j.1365-2621.2008.01888.x

Desobry, S.A., Netto, F.M. and Labuza, T.P. (1997). Comparison of Spray-drying, Drum-drying and Freeze-drying for $\beta$-Carotene Encapsulation and Preservation. Journal of Food Science, 62(6), 11581162. https://doi.org/10.1111/j.13652621.1997.tb12235.x

Dickinson, E. (2003). Hydrocolloids at interfaces and the influence on the properties of dispersed systems. Food Hydrocolloids, 17(1), 25-39. https:// doi.org/10.1016/S0268-005X(01)00120-5

Dolinsky, A.A. (2001). High-Temperature Spray Drying. Drying Technology, 19(5), 785-806. https:// 
doi.org/10.1081/DRT-100103770

Du, J., Ge, Z.Z., Xu, Z., Zou, B., Zhang, Y. and Li, C.M. (2014). Comparison of the Efficiency of Five Different Drying Carriers on the Spray Drying of Persimmon Pulp Powders. Drying Technology, 32 (10), 1157-1166. https:// doi.org/10.1080/07373937.2014.886259

Ersus, S. and Yurdagel, U. (2007). Microencapsulation of anthocyanin pigments of black carrot (Daucus carota L.) by spray drier. Journal of Food Engineering, 80(3), 805-812. https:// doi.org/10.1016/j.jfoodeng.2006.07.009

Faldt, P., Bergenstahl, B. and Carlsson, G. (1993). The Surface Coverage of Fat on Food Powders Analyzed by Esca (Electron Spectroscopy for Chemical Analysis). Food Structure, 12(12), 225-234.

Fang, Z. and Bhandari, B. (2012). Comparing the efficiency of protein and maltodextrin on spray drying of bayberry juice. Food Research International, 48(2), 478-483. https:// doi.org/10.1016/j.foodres.2012.05.025

Fazaeli, M., Emam-Djomeh, Z., Omid, M. and KalbasiAshtari, A. (2013). Prediction of the Physicochemical Properties of Spray-Dried Black Mulberry (Morus nigra) Juice using Artificial Neural Networks. Food and Bioprocess Technology, 6(2), 585-590. https://doi.org/10.1007/s11947-011-0648-x

Ferrari, C.C., Germer, S.P.M., Alvim, I.D., Vissotto, F.Z. and de Aguirre, J.M. (2012). Influence of carrier agents on the physicochemical properties of blackberry powder produced by spray drying. International Journal of Food Science and Technology, 47(6), 1237-1245. https:// doi.org/10.1111/j.1365-2621.2012.02964.x

Gharsallaoui, A., Roudaut, G., Chambin, O., Voilley, A. and Saurel, R. (2007). Applications of spray-drying in microencapsulation of food ingredients: An overview. Food Research International, 40(9), 1107 -1121. https://doi.org/10.1016/j.foodres.2007.07.004

Gonnissen, Y., Remon, J.P. and Vervaet, C. (2008). Effect of maltodextrin and superdisintegrant in directly compressible powder mixtures prepared via co-spray drying. European Journal of Pharmaceutics and Biopharmaceutics, 68(2), 277282. https://doi.org/10.1016/j.ejpb.2007.05.004

Goula, A.M. and Adamopoulos, K.G. (2003). Spray drying performance of a laboratory spray dryer for tomato powder preparation. Drying Technology, 21 (7), 1273-1289. https://doi.org/10.1081/DRT120023180

Goula, A.M. and Adamopoulos, K.G. (2008). Effect of maltodextrin addition during spray drying of tomato pulp in dehumidified air: II. powder properties. Drying Technology, 26(6), 726-737. https:// doi.org/10.1080/07373930802046377

Goula, A.M. and Adamopoulos, K.G. (2010). A new technique for spray drying orange juice concentrate. Innovative Food Science and Emerging Technologies, 11(2), 342-351. https:// doi.org/10.1016/j.ifset.2009.12.001

Grabowski, J.A., Truong, V.D. and Daubert, C.R. (2006). Spray-drying of amylase hydrolyzed sweetpotato puree and physicochemical properties of powder. Journal of Food Science, 71(5). https:// doi.org/10.1111/j.1750-3841.2006.00036.x

Horuz, E., Altan, A. and Maskan, M. (2012). Spray Drying and Process Optimization of Unclarified Pomegranate (Punica granatum) Juice. Drying Technology, 30(7), 787-798. https:// doi.org/10.1080/07373937.2012.663434

Jangam, S.V. and Thorat, B.N. (2010). Optimization of spray drying of ginger extract. Drying Technology, 28(12), 1426-1434. https:// doi.org/10.1080/07373937.2010.482699

Jayasundera, M., Adhikari, B., Adhikari, R. and Aldred, P. (2011). The effect of protein types and low molecular weight surfactants on spray drying of sugar-rich foods. Food Hydrocolloids, 25(3), 459469.

Jinapong, N., Suphantharika, M. and Jamnong, P. (2008). Production of instant soymilk powders by ultrafiltration, spray drying and fluidized bed agglomeration. Journal of Food Engineering, 84(2), 194-205.

j.jfoodeng.2007.04.032

Jouppila, K. and Roos, Y.H. (1994). Water Sorption and Time-Dependent Phenomena of Milk Powders. Journal of Dairy Science, 77(7), 1798-1808. https:// doi.org/10.3168/jds.S0022-0302(94)77121-6

Keogh, M.K., Murray, C.A. and O'Kennedy, B.T. (2003). Effects of ultrafiltration of whole milk on some properties of spray-dried milk powders. International Dairy Journal, 13(12), 995-1002. https://doi.org/10.1016/S0958-6946(03)00123-7

Kha, T.C., Nguyen, M.H. and Roach, P.D. (2010). Effects of spray drying conditions on the physicochemical and antioxidant properties of the Gac (Momordica cochinchinensis) fruit aril powder. Journal of Food Engineering, 98(3), 385-392. https://doi.org/10.1016/j.jfoodeng.2010.01.016

Khalilian Movahhed, M. and Mohebbi, M. (2016). Spray Drying and Process Optimization of Carrot-Celery Juice. Journal of Food Processing and Preservation, 40(2), 212-225. https://doi.org/10.1111/jfpp.12598 
Koç, B. and Kaymak-Ertekin, F. (2014). The effect of spray drying processing conditions on physical properties of spray dried maltodextrin. $9^{\text {th }}$ Baltic Conference on Food Science and Technology "Food for Consumer Well-Being" FOODBALT 2014, p. 243-247. Jelgava, Latvia.

Krishnan, S., Bhosale, R. and Singhal, R.S. (2005). Microencapsulation of cardamom oleoresin: Evaluation of blends of gum arabic, maltodextrin and a modified starch as wall materials. Carbohydrate Polymers, 61(1), 95-102. https:// doi.org/10.1016/j.carbpol.2005.02.020

Kurozawa, L.E., Park, K.J., and Hubinger, M.D. (2009). Effect of carrier agents on the physicochemical properties of a spray dried chicken meat protein hydrolysate. Journal of Food Engineering, 94(3-4), 326-333.

https://doi.org/10.1016/ j.jfoodeng.2009.03.025

Kwapinska, M. and Zbicinski, I. (2005). Prediction of Final Product Properties After Cocurrent Spray Drying. Drying Technology, 23(8), 37-41. https:// doi.org/10.1081/DRT-200065075

Lee, K.C., Yoon, Y.S., Li, F.Z. and Eun, J.B. (2017). Effects of inlet air temperature and concentration of carrier agents on physicochemical properties, sensory evaluation of spray-dried mandarin (Citrus unshiu) beverage powder. Applied Biological Chemistry, 60(1), 33-40. https://doi.org/10.1007/ s13765-016-0246-8

Loksuwan, J. (2007). Characteristics of microencapsulated $\beta$-carotene formed by spray drying with modified tapioca starch, native tapioca starch and maltodextrin. Food Hydrocolloids, 21(56), 928-935. https://doi.org/10.1016/ j.foodhyd.2006.10.011

Maa, Y.F., Nguyen, P.A., Sit, K. and Hsu, C.C. (1998). Spray-drying performance of a bench-top spray dryer for protein aerosol powder preparation. Biotechnology and Bioengineering, 60(3), 301-309. https://doi.org/10.1002/(SICI)1097-0290(19981105) $60: 3<301::$ AID-BIT5>3.0.CO;2-L

Mestry, A.P., Mujumdar, A.S. and Thorat, B.N. (2011). Optimization of spray drying of an innovative functional food: Fermented mixed juice of carrot and watermelon. Drying Technology, 29(10), 11211131. doi.org/10.1080/07373937.2011.566968

https://

Minemoto, Y., Hakamata, K., Adachi, S. and Matsuno, R. (2002). Oxidation of linoleic acid encapsulated with gum arabic or maltodextrin by spray-drying. Journal of Microencapsulation, 19(2), 181-189. https://doi.org/10.1080/02652040110065468
Mishra, P., Mishra, S. and Mahanta, C.L. (2014). Effect of maltodextrin concentration and inlet temperature during spray drying on physicochemical and antioxidant properties of amla (Emblica officinalis) juice powder. Food and Bioproducts Processing, 92 (3), 252-258. https://doi.org/10.1016/ j.fbp. 2013.08 .003

More Swati, K. and Wagh, M.P. (2014). Review on Spray Drying Technology. International Journal of Pharmaceutical, Chemical and Biological Sciences, 4(2), 219-225.

Muzaffar, K. and Kumar, P. (2016). Comparative efficiency of maltodextrin and protein in the production of spray-dried tamarind pulp powder. Drying Technology, 34(7), 802-809. https:// doi.org/10.1080/07373937.2015.1080724

Namaldi, A., Çalik, P. and Uludag, Y. (2006). Effects of spray drying temperature and additives on the stability of serine alkaline protease powders. Drying Technology, 24(11), 1495-1500. https:// doi.org/10.1080/07373930600961108

Nekkanti, V., Muniyappan, T., Karatgi, P., Hari, M.S., Marella, S. and Pillai, R. (2009). Spray-drying process optimization for manufacture of drugcyclodextrin complex powder using design of experiments. Drug Development and Industrial Pharmacy, 35(10), 1219-1229. https:// doi.org/10.1080/03639040902882264

Nesterenko, A., Alric, I., Silvestre, F. and Durrieu, V. (2013). Vegetable proteins in microencapsulation: A review of recent interventions and their effectiveness. Industrial Crops and Products, 42(1), $469-479$.

https://doi.org/10.1016/ j.indcrop. 2012.06 .035

Oakley, D.E. (2004). Spray Dryer Modeling in Theory and Practice. Drying Technology, 22(6), 1371-1402. https://doi.org/10.1081/DRT-120038734

Papadakis, S.E., Gardeli, C. and Tzia, C. (2006). Spray drying of raisin juice concentrate. Drying Technology, 24(2), 173-180. https:// doi.org/10.1080/07373930600559019

Pedroza-Islas, R., Vernon-Carter, E.J., DuránDomínguez, C. and Trejo-Martínez, S. (1999). Using biopolymer blends for shrimp feedstuff microencapsulation - I. Microcapsule particle size, morphology and microstructure. Food Research International, 32(5), 367-374. https:// doi.org/10.1016/S0963-9969(99)00099-X

Quek, S.Y., Chok, N.K. and Swedlund, P. (2007). The physicochemical properties of spray-dried watermelon powders. Chemical Engineering and Processing: Process Intensification, 46(5), 386-392. 
https://doi.org/10.1016/j.cep.2006.06.020

Rao, R.P.G. (2002). Development of spray dried juice blended skim milk powder. Brazilian Journal of Chemical Engineering, 19(4), 397-402.

Righetto, A.M. and Netto, F.M. (2005). Effect of encapsulating materials on water sorption, glass transition and stability of juice from immature acerola. International Journal of Food Properties, 8 (2), 337-346. https://doi.org/10.1081/JFP-200060262

Rodríguez-Hernández, G.R., González-García, R., Grajales-Lagunes, A., Ruiz-Cabrera, M.A. and Abud -Archila, M. (2005). Spray-Drying of Cactus Pear Juice (Opuntia streptacantha): Effect on the Physicochemical Properties of Powder and Reconstituted Product. Drying Technology, 23(4), 955-973.

https://doi.org/10.1080/DRT-200054251

Román-Guerrero, A., Orozco-Villafuerte, J., PérezOrozco, J.P., Cruz-Sosa, F., Jiménez-Alvarado, R. and Vernon-Carter, E.J. (2009). Application and evaluation of mesquite gum and its fractions as interfacial film formers and emulsifiers of orange peel-oil. Food Hydrocolloids, 23(3), 708-713. https://doi.org/10.1016/j.foodhyd.2008.06.005

Roos, Y. (2002). Importance of glass transition and water activity to spray drying and stability of dairy powders. Brazilian Journal of Chemical Engineering, 19(4), 397-402.

Roos, Y. and Karel, M. (1991). Water and Molecular Weight Effects on Glass Transitions in Amorphous Carbohydrates and Carbohydrate Solutions. Journal of Food Science, 56(6), 1676-1681. https:// doi.org/10.1111/j.1365-2621.1991.tb08669.x

Sagar, V.R. and Suresh Kumar, P. (2010). Recent advances in drying and dehydration of fruits and vegetables: A review. Journal of Food Science and Technology, 47(1), 15-26. https://doi.org/10.1007/ s13197-010-0010-8

Samborska, K., Gajek, P. and Kamińska-Dwórznicka, A. (2015). Spray drying of honey: The effect of drying agents on powder properties. Polish Journal of Food and Nutrition Sciences, 65(2), 109-118. https:// doi.org/10.2478/pjfns-2013-0012

Santana, A.A., Martin, L.G.P., de Oliveira, R.A., Kurozawa, L.E. and Park, K.J. (2017). Spray drying of babassu coconut milk using different carrier agents. Drying Technology, 35(1), 76-87. https:// doi.org/10.1080/07373937.2016.1160111

Shavakhi, F., Boo, H.C., Osman, A. and Ghazali, H.M. (2012). Effects of Enzymatic Liquefaction, Maltodextrin Concentration, and Spray-Dryer Air Inlet Temperature on Pumpkin Powder
Characteristics. Food and Bioprocess Technology, 5 (7), 2837-2847. https://doi.org/10.1007/s11947-0110686-4

Shi, Q., Fang, Z. and Bhandari, B. (2013). Effect of Addition of Whey Protein Isolate on Spray-Drying Behavior of Honey with Maltodextrin as a Carrier Material. Drying Technology, 31(13-14), 16811692. doi.org/10.1080/07373937.2013.783593

https://

Shishir, M.R.I. and Chen, W. (2017). Trends of spray drying: A critical review on drying of fruit and vegetable juices. Trends in Food Science and Technology, 65, 49-67. https://doi.org/10.1016/ j.tifs.2017.05.006

Shrestha, A.K., Ua-Arak, T., Adhikari, B.P., Howes, T. and Bhandari, B.R. (2007). Glass transition behavior of spray dried orange juice powder measured by differential scanning calorimetry (DSC) and thermal mechanical compression test (TMCT). International Journal of Food Properties, 10(3), 661-673. https:// doi.org/10.1080/10942910601109218

Singh, B. and Hathan, B.S. (2017). Process optimization of spray drying of beetroot Juice. Journal of Food Science and Technology, 54(8), 2241-2250. https:// doi.org/10.1007/s13197-017-2659-8

Sivarajalingam, S. (2009). Modelling and Control of a Spray Drying Process. Denmark: Technical University of Denmark, MSc. Thesis

Swenson, H.A., Kaustinen, H.M., Kaustinen, O.A. and Thompson, N.S. (1968). Structure of gum arabic and its configuration in solution. Journal of Polymer Science Part A-2: Polymer Physics, 6(9), 15931606. https://doi.org/10.1002/pol.1968.160060904

Tan, L.W., Ibrahim, M.N., Kamil, R. and Taip, F.S. (2011). Empirical modeling for spray drying process of sticky and non-sticky products. Procedia Food Science, 1, 690-697. https://doi.org/10.1016/ j.profoo.2011.09.104

Tengse, D.D., Priya, B. and Kumar, P.A.R. (2017). Optimization for encapsulation of green tea (Camellia sinensis L.) extract by spray drying technology. Journal of Food Measurement and Characterization, 11(1), 85-92. https:// doi.org/10.1007/s11694-016-9374-4

Tonon, R.V., Brabet, C. and Hubinger, M. D. (2008). Influence of process conditions on the physicochemical properties of açai (Euterpe oleraceae Mart.) powder produced by spray drying. Journal of Food Engineering, 88(3), 411-418. https://doi.org/10.1016/j.jfoodeng.2008.02.029

Tontul, I., Topuz, A., Ozkan, C. and Karacan, M. (2016). Effect of vegetable proteins on physical 
characteristics of spray-dried tomato powders. Food Science and Technology International, 22(6), 516524. https://doi.org/10.1177/1082013216629528

Tzannis, S.T. and Prestrelski, S.J. (1999). Moisture effects on protein-excipient interactions in spraydried powders. Natureof destabilizing effects of sucrose. Journal of Pharmaceutical, 88(3), 360-370. https://doi.org/10.1021/js9800127

Vehring, R., Foss, W.R. and Lechuga-Ballesteros, D. (2007). Particle formation in spray drying. Journal of Aerosol Science, 38(7), 728-746. https:// doi.org/10.1016/j.jaerosci.2007.04.005

Wang, S. and Langrish, T. (2009). A review of process simulations and the use of additives in spray drying. Food Research International, 42(1), 13-25. https:// doi.org/10.1016/j.foodres.2008.09.006

Wang, S. and Langrish, T. (2010). The use of surface active compounds as additives in spray drying. Drying Technology, 28(3), 341-348. https:// doi.org/10.1080/07373931003641404

Wang, S., Langrish, T. and Leszczynski, M. (2010). The effect of casein as a spray-drying additive on the sorption and crystallization behavior of lactose. Drying Technology, 28(3), 422-429. https://doi.org/10.1080/07373931003648631

Wang, W., Jiang, Y. and Zhou, W. (2013). Characteristics of soy sauce powders spray-dried using dairy whey proteins and maltodextrins as drying aids. Journal of Food Engineering, 119(4), 724-730.

https://doi.org/10.1016/ j.jfoodeng.2013.06.047

Wang, W. and Zhou, W. (2013a). Effect of maltodextrins on water adsorption and glass transition of spray dried soy sauce powders. $11^{\text {th }}$ International Congress on Engineering and Food (ICEF11), May 22 - 26, 2011. Athens, Greece: ICEF. Retreived from ICEF website: www.icef11.org/content/papers/fms/ FMS848.pdf

Wang, W. and Zhou, W. (2013b). Water Adsorption and Glass Transition of Spray-Dried Soy Sauce Powders Using Maltodextrins as Carrier. Food and Bioprocess Technology, 6(10), 2791-2799. https:// doi.org/10.1007/s11947-012-0992-5

Wang, W. and Zhou, W. (2015). Characterisation of spray dried soy sauce powders made by adding crystalline carbohydrates to drying carrier. Food Chemistry, 168, 417-422. https://doi.org/10.1016/ j.foodchem.2014.07.065

Yoshii, H., Soottitantawat, A., Liu, X.-D., Atarashi, T., Furuta, T., Aishima, S., Ohgawara, M. and Linko, P. (2001). Flavor release from spray-dried maltodextrin/gum arabic or soy matrices as a function of storage relative humidity. Innovative Food Science and Emerging Technologies, 2(1), 5561. https://doi.org/10.1016/S1466-8564(01)00019-4

Young, S.L., Sarda, X. and Rosenberg, M. (1993). Microencapsulating Properties of Whey Proteins. 1. Microencapsulation of Anhydrous Milk Fat. Journal of Dairy Science, 76(10), 2868-2877. https:// doi.org/10.3168/jds.S0022-0302(93)77625-0

Yousefi, S., Emam-Djomeh, Z. and Mousavi, S. M. (2011). Effect of carrier type and spray drying on the physicochemical properties of powdered and reconstituted pomegranate juice (Punica Granatum L.). Journal of Food Science and Technology, 48(6), 677-684. https://doi.org/10.1007/s13197-010-0195-x 